\title{
A LOVAK REJTETT SZEREPE A LOVASTERÁPIÁS MUNKÁBAN
}

\section{THE HIDDEN ROLE OF HORSES IN EQUINE-ASSISTED THERAPY}

\author{
Koltai Blanka Sára ${ }^{1 *}$, Dr. Devosa Iván Ph.D. ${ }^{2}$, Dr. Tiszai Luca Ph.D. ${ }^{1}$, Dr. habil. PaedDr. Nagy \\ Melinda Ph.D. ${ }^{3}$ \\ ${ }^{1}$ Gyógypedagógus-képző Intézet, Juhász Gyula Pedagógusképző Kar, Szegedi Tudományegyetem, \\ Magyarország \\ ${ }^{2}$ Egészségtudományi Kutatóműhely, Tanítóképző Főiskolai Kar, Károli Gáspár Református Egyetem, \\ Magyarország \\ ${ }^{3}$ Tanítóképző Kar, Selye János Egyetem, Szlovákia \\ https://doi.org/10.47833/2020.3.ART.005
}

\section{Kulcsszavak:}

állatasszisztált terápiák

lovasterápia

lovak

fejlesztés

idegrendszer

\section{Keywords:}

animal-assisted therapy

horse-riding therapy

horses

promotion

nervous system

\section{Cikktörténet:}

Beérkezett 2020. november 15. Átdolgozva 2020. November 25. Elfogadva 2020. november 30.

\begin{abstract}
Összefoglalás
Az állatasszisztált terápiák napjainkban egyre nagyobb népszerüségnek örvendenek, melyek közül a lovasterápia az egyik legnépszerübb. Fontos kiemelni, hogy a terápiára nem minden ló alkalmas, ezért fontos a terpiás munka megkezdése előtt a megfelelő ló kiválasztása és képzése. A kiválasztásnál elsősorban fontos figyelembe venni lovak a méretét, mozgását, nemét, korát, vérmérsékletét és munkakedvét. $A$ terápiás munka során nemcsak a szakembernek kell magas szintü tudással rendelkezniük, hanem a lovaknak is. A lovasterápiára általában jól alkalmazható fajták pl.: a Haflingi, a Fjord és a Hucul.
\end{abstract}

\begin{abstract}
Animal assisted therapies are gaining in popularity these days, of which equestrian therapy is one of the most popular. The success of the therapy is the appropriate horse. It is important that not all horses are suitable for therapy, so we have to select and train the appropriate horse before beginning therapeutic work. In selecting, it is primarily important to consider the size, movement, sex, age, temperament, and work ethic of horses. In therapeutic work, not only the professional should have a high level of knowledge, but also horses. Types that are generally suitable for equestrian therapy include Haflingi, Fjord and Hucul.
\end{abstract}

\section{Bevezetés}

Napjainkban egyre nagyobb népszerüségnek örvendenek az állatasszisztált terápiák. A legnépszerübb terápiák közé a kutyás és lovasterápiákat soroljuk, ugyanakkor már alkalmaznak delfineket, nyulakat és még alpakkákat is erre a célra. Az állatok pozitív hatását az emberekre a mindennapokban is tapasztalhatjuk, hiszen a háziállatok évszázadok óta az emberekkel élnek. Az

\footnotetext{
* Kapcsolattartó szerző. Tel.: +36 204858506

E-mail cím: koltai.blanka997@gmail.com
} 
emberekre gyakorolt jótékony hatását az állatoknak az 1960-as években Boris M. Levinson pszichiáter kezdte el vizsgálni. [1]

A lovasterápia sok olyan fejlesztési lehetőséget biztosít a lovasok számára, melyeket földről nem vagy nehezebben érhetünk el. A terápiához kiemelten fontos a megfelelő társ, a megfelelő ló kiválasztása és folyamatos képzése. Nem minden ló alkalmas a terápiás munkára, ezáltal figyelembe kell vennünk a lovak adottságait: méret, mozgás, nem, kor, vérmérséklet és munkakedv. A terápiához a megfelelő ló mellett a megfelelő szakember is szükséges.

\section{A lovak alkalmazása a terápiás munkában}

A terápiás munkára nem minden ló alkalmas. A munkára alkalmas lovak kiválasztásakor számos szempontot figyelembe kell venni, melyek után kezdődhet meg a kiképzésük majd a vizsgáztatásuk. A lovak belső és külső tulajdonságait is hasznosítjuk a terápiás munka alatt. A belső tulajdonságok között megtaláljuk, hogy miért is alkalmazhatóak terápiás munkára: szelídíthetők, csoportban élő állatok, házasíthatók, együttmüködési készséggel rendelkeznek, engedelmesek, illetve szükséges, hogy a temperamentumuk is megfelelő legyen. A külső tulajdonságaik alatt értjük a méretüket, a teherbírásukat, a külső megjelenésüket, testhőmérsékletüket és a mozgásfolyamatukat. [2]

A terápiás munka szempontjából a lovaknak három jármódját alkalmazzuk: a lépést, az ügetést és a vágtát. A három jármód lábsorrendje és ütemeinek száma eltérö.

\subsection{A lovasterápia}

„Lovas Nemzet a magyar!” Világszerte elismert mondás. A lovaglásnak rendkívül sok válfaja és célja ismert, ezek közül én a fejlesztő hatását ragadom meg a lovasterápia által.

Mint fentebb is említésre került Magyarországon az állatasszisztált terápiák közül a lovasterápia egyre nagyobb népszerüségnek örvend manapság. A lovasterápia a gyógylovaglás egyik ága a parasport mellett. Gyógylovaglásnak nevezzük gyüjtőfogalomként mindazon lóval végzett foglalkozásokat, melyek során a ló segíti a fejlesztést, míg a parasport vagy az akadályozott személyek sportlovaglása, a fogyatékkal élő személyek szabadidős vagy verseny- sportja a lovas szakágaknak megfelelő (díjlovaglás, fogathajtás) színtereken. [3]

A lovasterápiának 3 területe van: a hippoterápia, gyógypedagógiai célú lovaglás és lovastorna és a lovas pszichoterápia. A hippoterápiát gyógytornász vagy szomatopedagógus végzettségü lovasterapeuták végzik, a gyógypedagógiai célú lovaglás és lovastornát gyógypedagógusok végzik, míg a lovas pszichoterápiát pszichológus lovasterapeuták végzik. A hippoterápia gyógytorna alapú, a gyógypedagógiai lovaglás és lovastorna fejlesztő nevelő célú, mely különböző eszközök, játékok bevonásával is történhet, ugyanakkor a foglalkozás során a lovaglás és a lovastorna elemeit is alkalmazzák. A gyógypedagógiai lovaglás és lovastorna lehet egyéni vagy csoportos. [4] A lovas pszichoterápia a lóval való foglalkozás pszichés hatásait használja terápiás céllal. [3] 


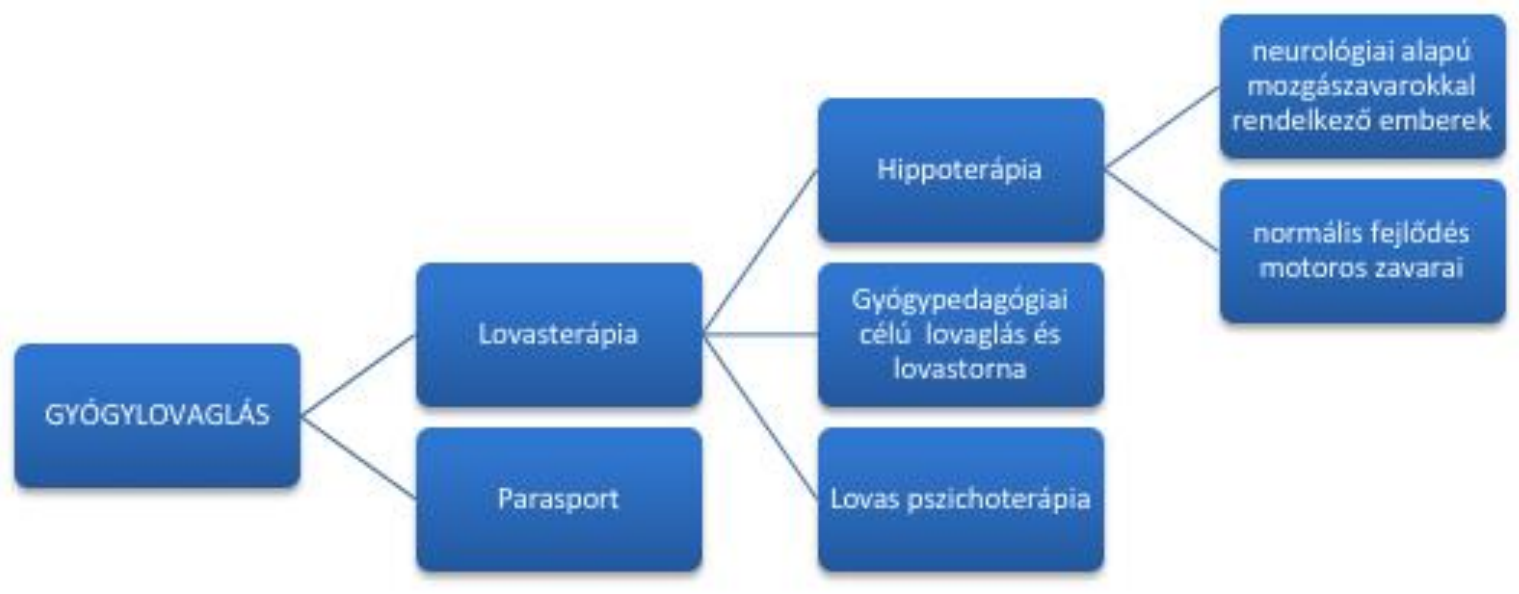

1. ábra: Lovasterápia helye és területei a gyógylovaglás rendszerében. [5]

\subsection{A terápiás munka felépítése}

A foglalkozások nem csupán egy lovaglásból állnak, fontos a lovasokat a lovak körüli teendőkbe is bevonni. Ezen munkafolyamatok során is mélyül a ló-lovas kapcsolat, illetve a lovasok megtanulnak gondoskodni egy élölényröl, megtapasztalhatják, hogy fontosak és szükség van rájuk hiszen számít, amit csinálnak. A lovak körüli munkák végzése a szabálykövetést is elösegíti, hiszen a lovak körül rengeteg szabályt be kell tartanunk. A lovasok egy náluk sokkal nagyobb élölénnyel kommunikálnak, ezáltal önbizalmat is szereznek a munkafolyamatok során. Lovaglás előtt fontos bevonnunk és megtanítanunk a lovasainkat a lóápolásra. A lovak megfelelő szerszámozása kiemelten fontos, ezért a lovasok ebbe a munkafolyamatba fokozatosan kapcsolódnak be. Fontos a lovasokat arra neveljük, hogy a lovaglás után is lovairól gondoskodjanak: a szerszámok elpakolása, a munka utáni lóápolás és jutalmazás.

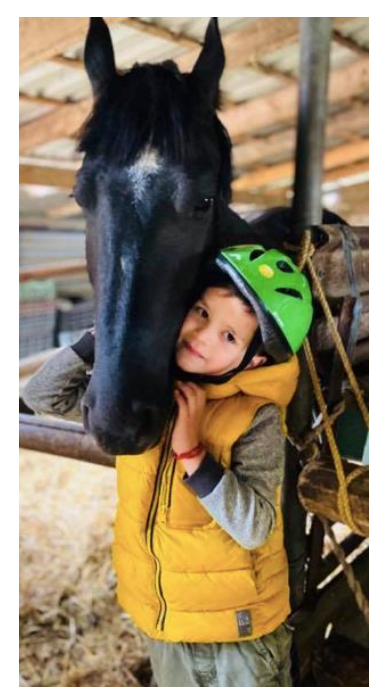

2. ábra: Ló-lovas kapcsolat (saját ábra) 
A lovasterápia a többi állatasszisztált terápiához képest azzal a nagy előnnyel jár, hogy a ló külső és belső tulajdonságaiból adódóan a terápiára érkezők nemcsak a jelenlétüket élvezhetik, hanem a hátukra felülve további tapasztalatokat gyüjthetnek. A ló hátán ülő lovas számára sokoldalú fejlesztési lehetőség nyílik, hiszen a ló passzívan átmozgatja lovasát. [3] A ló mozgása a hátán ülő lovas mozgását háromdimenzióssá alakítja. A ló mozgásimpulzusai a lovas csípőjén keresztül a gerincoszlopán vezetve eljutnak a lovas agyáig, ahol válaszreakciókat alakít ki. [3] A ló mozgásimpulzusai által a lovas mozog jobbra-balra, fel-le és elöre-hátra. A ló ezen mozgások alapján mozgatja át passzívan a lovasát. Ezen impulzusok által a lovas idegrendszere, érzékelése és egyensúlyozási képessége folyamatos fejlesztés alatt áll a foglalkozások során. [5]

A gyógypedagógiai lovaglás és lovastorna során a lovastorna elemeit alkalmazva fejlődik a lovas szem-kéz koordinációja, a koncentrációja, a testsémája, az önbizalma, az észlelése (pl.: mélyészlelés). [6] A lovastorna elemei soroljuk pl.: a térdelést, guggolást, a malmot, a törökülést, a zászlót, a mérleget stb. [5]

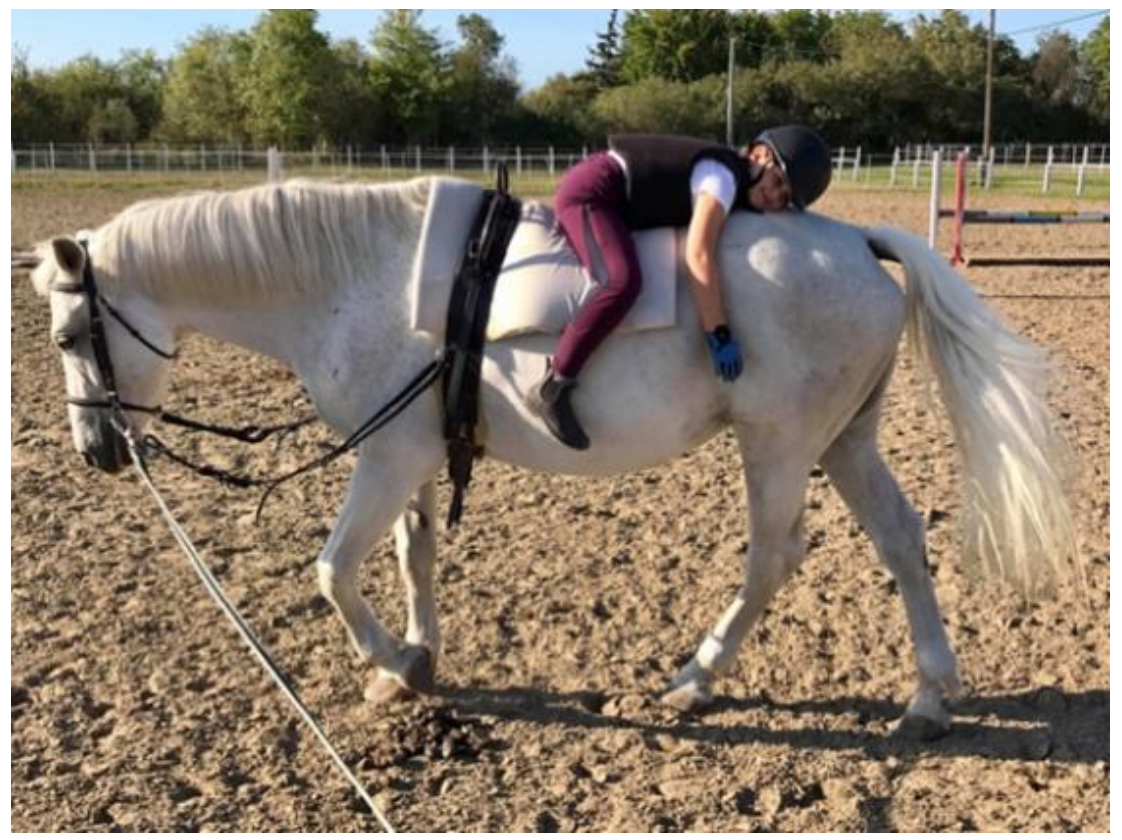

3. ábra: Lovastorna elemének alkalmazása lóháton. [5]

A foglalkozások során különböző eszközöket és fejlesztő játékokat is alkalmazhatunk, az egyes területek fejlesztéséhez az egyéni igényeknek megfelelően. Az eszközök, játékok további célja, hogy fenntartsa a lovas motivációját, figyelmét. Mindezek bevonásával további területek fejleszthetősége is megvalósul (pl. a kognitív funkciók érzékelés, észlelés, emlékezet, figyelem,

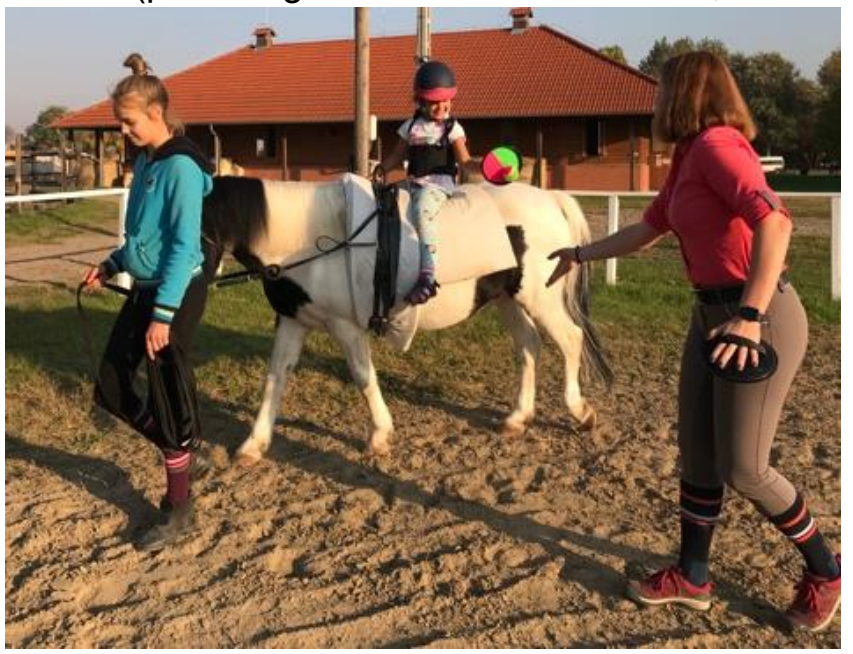


gondolkodás, a beszédfejlesztés, a motoros és orientációs képességek, az érzelmi állapot, az akarati cselekvések befolyásolása, a szocializáció elősegítése stb.) [6] A fejlesztő játékoknak csak a kreativitás szab határokat. Fejlesztő játék pl.: csipesz, báb, kugli, labda, buborékfújó, különböző kártyák, gyöngyök, kirakók, karikák, babzsák. [5]

4. ábra: Fejlesztő játék alkalmazása vezetett lovon történő foglalkozáson. [5]

\section{A ló személyiségének és fiziológiájának szerepe}

A lovak ménesben élő állatok, így a társaság a természetes közege. A méneseben a hierarchiának megfelelően minden lónak megvan a saját pozíciója, melyért megküzdenek. A lovak kommunikálnak egymással, mint pl.: a testnyelv és az érintés. [4] A lovak úgy tekintenek az emberrel, mint akivel kapcsolatot tudnak teremteni a ménesösztönnek köszönhetöen. Velünk is testnyelvvel kommunikálnak, egyenrangúnak, felettük vagy alattuk állónak vagy ellenségnek tartanak számon. Érdekessé teszi az ember-ló kapcsolatot, hogy míg a ló zsákmányállat az ember ragadozó. [6]

A ló lovas kapcsolat alapjait jól összefoglalja Miller. „A lóban megtestesülö (...) személyiségbeli jellemzők azonosak az emberben megtestesültekkel. (...) Talán a lovak megértése iránti vágyunk nem is más, mint magunk és környezetünk megértésének szándéka." [7] A ló folyamatosan, mint egy tükröt tart a lovasa elé, vagyis a ló mindig a lovas viselkedésének megfelelöen reagál. A ló nem csak a viselkedéseinkre vagy érzelmeinkre reagál, hanem a mozgásunkat is követi. Jól képzett figyelmes ló, a lovasa mozgását is érzékeli (pl.: a gyermek kibillen egyensúlyából a ló megáll).

A foglalkozások során a lovasok nem csak egy terápiát kapnak a lovaglások alkalmával, hanem egy társat, egy barátot, aki nem utasítja el őket, elfogadja őket úgy ahogy vannak, aki nem ítéli meg őket és aki melegséget sugároz feléjük. A melegséget fizikálisan is sugározza, mivel a ló testhőmérséklete magasabb kb. $38^{\circ} \mathrm{C}$, mint az emberé.

\subsection{A lovak fejlesztő hatása a lovasterápiában}

A lovaglás során a ló passzívan átmozgatja a lovas teljes testét. [3] A foglalkozások során ezáltal, a lovas idegrendszere folyamatos fejlesztés alatt áll. A terápia során kiemelten fontos a ló mozgása. A hátsó lábak mozgása eredményezi a ló keresztcsontjának a mozgását, illetve azon keresztül a ló hátának a mozgását. [8] A lovas a lovon ül, ezáltal a hátsó lábakból eredő rezgések a ló hátán vezetődve a lovasra is hatással vannak. A ló kb. 90-110-et lép egy perc alatt, ezáltal egy 30 perces lovaglás során 3000 fiziológiás impulzust közvetíthet a lovas felé [4] A lovasra gyakorolt impulzusok fejlesztő hatással vannak az idegrendszerre is. „Amennyiben egy gyermeknél koraszülés következtében ezeknek az érzéki tapasztalatoknak a folyamata megszakadt, a lovasterápia azokat pótolhatja, helyettesítheti. Fejleszti az idegösszeköttetéseket, vagy akár új idegmüködéseket is beindíthat" [9] Az idegi összeköttetéseket fejleszti, vagy akár új idegsejtmüködéseket is beindíthat [9] amelyek a mozgás folyamatát támogatják, ennek köszönhetően fejleszti a koordinációt, a mozgásminták elsajátítását, rögzítését. A gyógypedagógiai célú lovaglás és lovastorna során a gyógypedagógia és a lovaglás fejlesztő hatásai egymást kiegészítve fejlesztik a lovast. Különböző eszközök bevonásával további lehetőségeink adódnak pl. a kognitív funkciók (érzékelés, észlelés, emlékezet, figyelem, gondolkodás), a beszédfejlesztés, a motoros és orientációs képességek, az érzelmi állapot, az akarati cselekvések befolyásolása, a szocializáció elősegítése stb. érdekében. [6]

A ló nem mit eszköz, hanem mint társ van jelen a foglalkozásokon. [3] A terápia egyik alap célja a ló lovas kapcsolat mélyítésének elösegítése. A foglalkozások történhetnek egyénileg, melyek során a lovas szabadon lovagolva követi a terapeuta utasításait. A terápiás munka folyhat még 
futószáron és vezetett lovon is. A ló a terapeuta utasításait követve segíti lovasát, mindez a vezetett lovon történő fejlesztések során a lóvezető segítségével valósul meg. [5]

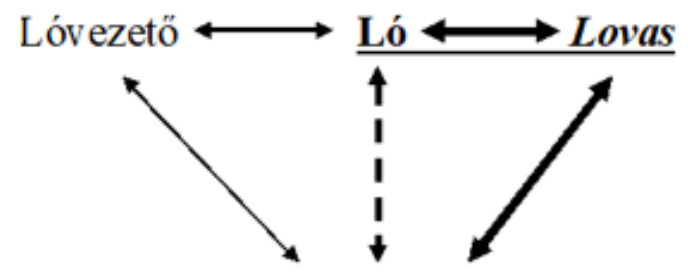

Terapeuta

5. ábra: Lovak szerepe a team munkában. [5]

\subsection{A terápiára alkalmas lovak kiválasztásának szempontjai}

A terápiára alkalmas lovak kiválasztása a következő szempontok alapján történik: méret, mozgás, nem, kor, vérmérséklet és munkakedv.

Marmagasságuk alapján a lovakat 3 csoportra oszthatjuk: póni, kisló és ló. A póni kategóriába a $120 \mathrm{~cm}$-nél alacsonyabb fajtákat soroljuk (pl.: shetland póni). A kisló kategóriába a $120 \mathrm{~cm}$-nél magasabb, ugyanakkor $148 \mathrm{~cm}$-nél alacsonyabb fajtákat soroljuk (pl.: Haflingi, Hucul). A ló kategóriába a $148 \mathrm{~cm}$-nél magasabb fajtákat soroljuk (pl.: magyar sportló, hannoveri) [10] A lovak méretét fontos a lovasok egyéni igényeihez igazítani: fontos figyelembe venni a felépítésüket és magasságukat, a hátuk hosszúságát és szélességét.

Alacsonyabb lovas számára az alacsonyabb marmagasságú ló szükséges, míg a magasabb lovas számára a magasabb marmagasságú ló szükséges. Fontos a ló teherbírását is figyelembe venni. A lovak méretét fontos a lovasok egyéni igényeihez igazítani: fontos figyelembe venni a felépítésüket és magasságukat, a hátuk hosszúságát és szélességét. [4] Terápiás munkára nagy általánosságban a kisló méretü lovak a legalkalmasabbak: Haflingi, Fjord.

A mozgásuk fontos, hogy ép és tiszta legyen. A terápia szempontjából 3 jármód kulcsfontosságú: a lépés, az ügetés és a vágta. A lépés 4 ütemű jármód, mely során a ló azonos oldali lábaival lép, de nem egy időben. Nincs lebegőfázis, mivel a lónak az egyik lába mindig a talajon van. Az ügetés 2 ütemű jármód, mely során van lebegőfázis, mivel egyszerre lépnek az átlós lábak. A vágta 3 ütemü jármód, mely során van lebegőfázis. A vágta lábsorrendje a következő: külső hátsó láb, belső hátsó és a külső hátsó láb egyszerre, majd a belső első láb nyúlik hosszan előre. Fontos, hogy a jármódok ütemei eltérőek, ennek megfelelően a terápia során a mozgásimpulzusok változnak. A terápiás ló lépésével szemben elvárás, hogy a hátsó lábakkal a ló lépjen az első patanyomok elé. Minden jármódban fontos, hogy szabályos és ütemes mozgása legyen. [10]

A nemük alapján megkülönböztetünk kancát, mént és heréltet. A heréltek a legalkalmasabbak a terápiás munkára, általában kiegyensúlyozottak és nyugodtak. A kancák is alkalmasak lehetnek a terápiás munkára, ugyanakkor sárlási időszakban kiegyensúlyozottságuk felborulhat. A mének nem alkalmasak a terápiás munkára.

A testtömeg, méret, csontozat, külső forma és vérmérséklet alapján csoportosítva megkülönböztetünk: hidegvérű és melegvérü fajtákat. A melegvérű fajták kisebb testtömegűek, vékonyabb csontozatúak, finomabb felépítésűek, élénk vérmérsékletű lovakat soroljuk (pl.: kisbéri félvér). A hidegvérü fajták nagyobb testtömegüek, erősebb csontozatúak, dús, hosszú szőrökkel rendelkező, külső ingerekre lassabban reagáló, nagyobb fizikai teljesítményt hosszabb idegig nyújtó lovakat soroljuk (pl.: magyar hidegvérü). A terápiás munkára a hidegvérű fajták az alkalmasak.

A koruk alapján az 5 évnél fiatalabb lovak vérmérsékletük miatt nem alkalmasak. Fontos a terápia során, hogy a ló szívesen dolgozzon, könnyen lehessen vezetni, ugyanakkor legyen türelmes (pl.: le- és felszálláskor). [11] 


\section{4. Összegzés}

A lovasterápia sikerességének alapja a megfelelő ló kiválasztása, mely a terápiás célokhoz optimális. Figyelnünk kell a ló személyiségét (nyugodt legyen, jól bírja a monoton feladatok hosszú időn keresztüli végrehajtását...stb), és a fiziológiáját (lépéshossz, magasság...stb). Ha ezeket e tényezőket nem megfelelően választjuk ki, a terápiás munka effektivitása jelentősen csökken.

A terápiára a fentiek alapján a legalkalmasabbak a tiszta mozgású, erős csontozatú, 5 évnél idösebb, herélt kislovak. Arra nincs megkötés, hogy ezek a lovak mely fajtából kell kikerüljenek, de nagyobb eséllyel járunk sikerrel, ha a kiválasztáskor pl.: Haflingi, Hucul vagy Fjord lovak közül választunk.

\section{Köszönetnyilvánítás}

Az Innovációs és Technológiai Minisztérium ÚNKP-20-1 - SZTE-333 kódszámú Új Nemzeti Kiválóság Programjának a Nemzeti Kutatási, Fejlesztési és Innovációs Alapból finanszírozott szakmai támogatásával készült.

\section{Irodalomjegyzék}

[1] Pászk Norbert (2019): Állatok hatása az emberek egészségi állapotára. Egészségtudományi Közlemények, 9. kötet, 2. szám pp. 32-36. Miskolc

[2] Düe M., Miesner K., Miesner S., Plewa M., Putz M., Veltjens-Otto_Erley C. (2005): A jól képzett ló, Mezőgazda Kiadó, Budapest.

[3] Wipke C. Hartje (2012): Lovasterápia: gyógypedagógiai lovaglás, lovas pszichoterápia. Mezőgazda, Budapest.

[4] Bozori Gabriella (2002): Lovasterápia - gondolatok vázlatok a gyógypedagógiai lovaglás és lovastorna témaköréböl. Polu-Press Kft., Székesfehérvár.

[5] Koltai Blanka Sára, Devosa Iván, Tiszai Luca (2019): Gyógypedagógia a lovaglásban, avagy lovaglás a gyógypedagógiában = Special Education in Horse Riding, or Horse Riding in Special Education. GRADUS, 7 (1). pp. 157-166. ISSN 2064-8014

[6] Schéder Veronika (2017): Lovasterápia, A neuro- és pszicholingvisztikai zavarok rehabilitációjában. Nyíregyháza

[7] Miller, M. (2012). Értsük meg a ló viselkedését! Budapest: Mezőgazda Kiadó.

[8] Bosch, S., Serra Bragança, F., Marin-Perianu, M., Marin-Perianu, R., van der Zwaag, B., Voskamp, J., ... \& Havinga, P. (2018). EquiMoves: a wireless networked inertial measurement system for objective examination of horse gait. Sensors, 18(3), 850. DOI: https://doi.org/10.3390/s18030850

[9] Büki Görgy (2006): A hippoterápia neurofizikai alapjai in: Schéder Veronika (2017): Különleges bánásmód lóasszisztált foglakozásokon. Különleges Bánásmód I. évf 2015/1. szám 79-89

[10] dr. Wagner Kinga (2010): Lovasvizsga felkészítő könyv. Tolnai Kft.

[11] Bozori Gabriella (2011): A gyógypedagógiai lovaglás és lovastorna, mint a gyógypedagógiai terápiák egyfajta lehetősége. Budapest. 